\title{
Sharia Marketing and Employee Intelligence on Public Trust in Indonesian Islamic Banking
}

\author{
Muhammad Rijalus Sholihin ${ }^{1}$, Imam Abrori ${ }^{2}$ \\ ${ }^{1}$ Department of Accounting, STIE Widya Gama Lumajang \\ ${ }^{2}$ Department of Management, STIE Widya Gama Lumajang \\ Email: muhammadrijalus@gmail.com
}

A R T I C L E IN F O

Received:

5 January 2021

Revised:

4 March 2021

Accepted:

8 March 2021
A B S T R A C T

The development of the Islamic banking system in Indonesia is carried out by a dual banking system within the framework of the Indonesian Banking Architecture (API). This has received a good response from the community so that it can create progressive trust. In addition to the sharia system label, there are several aspects that are thought to be factors in increasing public trust, including sharia marketing strategies and employee intelligence. The strategic process is the main pillar in gaining public attraction and trust. Likewise with the capabilities or intelligence of employees which can increase public trust. For this reason, this study aims to examine and analyze Islamic marketing and employee intelligence as an effort to increase public confidence in Islamic banking in Indonesia. This research was conducted in Jember Regency with a sample size of 100 respondents. The analytical method used is multiple linear regression analysis. The results of this study indicate that Islamic marketing has a significant and significant effect on public trust in Islamic banking, while employee intelligence does not show an effect on public trust in Islamic banking. The coefficient of determination obtained with an R Square value of $7.8 \%$, this shows that public trust can be explained by the existence of Islamic marketing and the intelligence of Islamic marketing employees and employee intelligence.

Keywords: Sharia Marketing, Employee Intelligence, Public Trust

Cite this as: Sholihin, M. R., Abrori, I. (2020). Sharia Marketing and Employee Intelligence on Public Trust in Indonesian Islamic Banking. Wiga : Jurnal Penelitian Ilmu Ekonomi, 11(1), 12-18. https://doi.org/10.30741/wiga.v11i1.428

\section{INTRODUCTION}

The development of the Islamic banking system in Indonesia is carried out within the framework of a dual-banking system or a dual banking system within the framework of the Indonesian Banking Architecture (API), to present a more complete alternative banking services to the Indonesian people. Taken together, the Islamic banking system and conventional banking 
synergistically support the mobilization of public funds more broadly to increase the capacity for financing sectors of the national economy. With the enactment of Law No.21 of 2008 concerning Islamic Banking which was issued on July 16, 2008, the development of the national Islamic banking industry has an adequate legal basis and will encourage its growth even more rapidly. With its impressive developmental progress, which has achieved an average asset growth of more than $65 \%$ per year in the last five years, it is hoped that the role of the Islamic banking industry in supporting the national economy will be increasingly significant. (www.bi.go.id)

Islamic banking continues to plague in urban to rural areas, both in the form of large-scale government banks and small-scale private banks. The operation of sharia banks, which are deemed insufficient to reach small and medium-sized businesses, emerged efforts to establish micro sharia banks and financial institutions, such as the Islamic People's Financing Bank (BPRS) and Baitul Maal Wat Tamwil (BMT) which aims to overcome regional operational obstacles. With the intense competition between Islamic financial institutions, BMT is trying to maintain its existence in society.

Humans can be said to be creatures of character. Humans can also be interpreted as concepts and facts, an idea and even an individual reality. In relation to the human environment, it is not without the word social which has treatment and strength. Human resources are one of the supporters of implementing an activity in organization. The emergence of the need to assist the organization in carrying out its objectives is professionalism at work. The need for professionalism shows that the role of human resources is increasingly playing a role in achieving organizational success. The level of human intelligence or intelligence of a person is different from one individual to another, there are many ways to increase the level of one's intelligence in order to achieve the main goal in an organizational activity, this level of human resource thinking is expected to be able to encourage and motivate every group to achieve public trust in Islamic banking. especially in Indonesia.

Along with the development and growth of the Islamic banking industry, Islamic Commercial Banks (BUS) are competing to attract public interest to save at their respective banks. Various strategies were used to make people who had saved their savings become loyal and to attract other bank members to move their deposits from other banks to that bank. One of the strategies undertaken is to carry out promotions by offering products owned by a bank to the public through print or electronic media and so on. Promotional activities carried out by sharia banking are included in bank marketing management activities which must be carried out as effectively and efficiently as possible and able to attract public interest so that the bank's goals can be achieved properly.

In the Islamic economic system, interest can be said to be usury, which is haram in the eyes of Islam. Therefore, as a substitute for this, the Islamic economic system replaces with another term, namely profit sharing, which is considered lawful in Islam based on the Koran and Al-Hadith. In some of its applications, the provisions for the profit sharing of the business must be determined at the beginning or in the initial contract the business contract has been agreed by several parties who will carry out the contract. Some other concepts in Islamic banking will at least be more trusted by the public, especially Muslims. Seeing the various facts that exist that the population of Islam is more dominant among the people, various Islamic banking products will also be able to help people get their desires from the perspective of Islamic banking. So that the specific objective in this study is to determine the extent to which Islamic marketing and employee intelligence are able to increase the level of public trust in Islamic banking in Indonesia, either partially or simultaneously. 


\section{METHOD}

In this study, the method used is quantitative research methods. The sample taken is a number of 100 respondents who have been calculated using the formulaSlovinwith data collection using questionnaires with a Likert scale. Analysis of the data used in this study using multiple linear regression analysis techniques. Some of the tests used in the instrument test are the validity test with a limit of r 0.3 (Sugiyono, 2015: 165) and a reliability test with a Cronbach Alpha limit (Kurniawan, 2014: 102). Then in the classical assumption test, namely the normality test using PP Plot with the residual point being near the diagnostic line (Umar, 2011: 181), the multicollinearity test with a VIF value limit $<10$ and a tolerance value of more than 0.1 and the heteroscedasticity test using the Scatterplot test ( Kurniawan, 2014: 157). Furthermore, to test the hypothesis using the $t$ test or partial test by calculating the coefficient of determination using R Square (Paramita \& Rizal, 2018: 82).

\section{RESULTS AND DISCUSSION}

Table 1.1 Description of Respondents

\begin{tabular}{lcc}
\hline & Frequency & Percentage (\%) \\
\hline Age (years) & 5 & $5 \%$ \\
$20-24$ & 7 & $7 \%$ \\
$25-29$ & 23 & $23 \%$ \\
$30-34$ & 13 & $13 \%$ \\
$35-39$ & 24 & $24 \%$ \\
$40-44$ & 23 & $23 \%$ \\
$45-49$ & 5 & $5 \%$ \\
$>50$ & & \\
Gender & 50 & $50 \%$ \\
Male & 50 & $50 \%$ \\
Women & & \\
Last education & 5 & $5 \%$ \\
Junior High & 32 & $32 \%$ \\
High school & 13 & $13 \%$ \\
D3 & 37 & $37 \%$ \\
S1 & 13 & $13 \%$ \\
S2 & 0 & $0 \%$ \\
Others & & \\
\hline
\end{tabular}

Source: data processing results (2020)

Based on table 1.1, it shows that the age category that most trusts in Islamic banking is 40-44 years old. In the gender category where 50 people $(50 \%)$ are male and 50 people $(50 \%)$ are female. Public trust in Islamic banking in terms of status, is dominated by people who have the latest S1 education as many as 37 people $(37 \%)$.

Table 1.2 Validity Test Results

\begin{tabular}{|c|c|c|c|c|}
\hline Questionnaire & $r$ count & Information & $\begin{array}{c}\text { Cronbach's } \\
\text { Alpha }\end{array}$ & Information \\
\hline \multicolumn{5}{|l|}{ Sharia Marketing (PS) } \\
\hline - PS1 & 0.801 & Valid & & \\
\hline - $\quad$ PS2 & 0.613 & Valid & 0.862 & Reliable \\
\hline - $\quad$ PS3 & 0.779 & Valid & & \\
\hline - $\quad$ PS4 & 0.747 & Valid & & \\
\hline - $\quad$ PS5 & 0.766 & Valid & & \\
\hline
\end{tabular}




\begin{tabular}{lllll}
\hline $\begin{array}{l}\text { Employee intelligence } \\
\text { (IK) }\end{array}$ & & & & \\
- IK1 & 0.796 & Valid & & \\
- IK2 & 0.536 & Valid & 0.823 & Reliable \\
- IK3 & 0.779 & Valid & & \\
- IK4 & 0.746 & Valid & & \\
- IK5 & 0.630 & Valid & & \\
\hline Public Trust (KM) & & & & Reliable \\
- KM1 & 0.833 & Valid & & \\
- KM2 & 0.676 & Valid & 0.818 & \\
- KM3 & 0.836 & Valid & & \\
- KM4 & 0.531 & Valid & & \\
- KM5 & 0.555 & Valid & & \\
\hline
\end{tabular}

Source: data processing results (2020)

Based on table 4.4, it can be seen that the results of the calculation of the correlation coefficient all have a valid status, because the calculated $r$ value is greater than the predetermined criteria, which is 0.3. In the calculation of the validity test above, it can be concluded that the instrument and all statement items in this study have met the requirements and can be said to be valid as a measuring tool because it can dig up the required data and information.

So it can be concluded that the questionnaire used to measure sharia marketing variables, employee intelligence and public trust in Islamic banking is reliable because all variables are more than 0.60 in accordance with the provisions of Cronbach Alpha. So that the questionnaire used is a reliable questionnaire because if it is used to measure again it will give no different results to the same subject at different times.

Table 1.3 Recapitulation of Classical Assumption Test Results

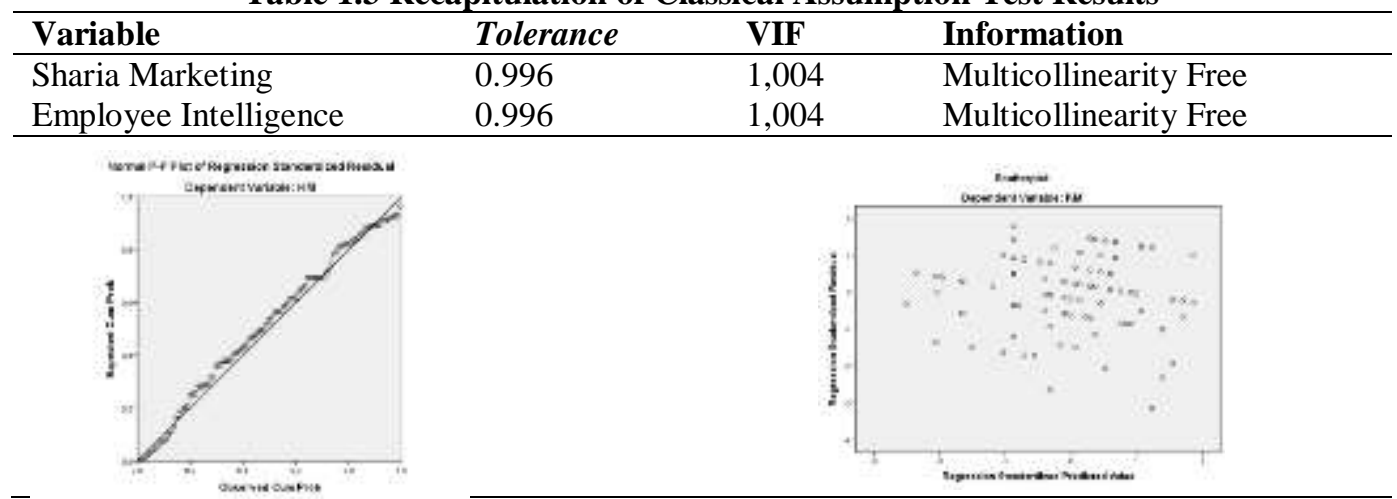

Source: data processing results $(2020)$

The results of the normality test in this study met the data criteria and the residuals were said to be normal. The multicollinearity test results show tolerance values, namely 0.996 and 0.996 , which are greater than 0.1 and VIF values of 1.004 and 1.004 are less than 10. Based on these results, the residual model meets the multicollinearity test criteria so that the residual model is declared free from multicollinearity or there is no correlation between variables. The results of the heteroscedasticity test, the location of the residuals spread without forming a specific pattern so that the residual model meets the heteroscedasticity test criteria or the residual model is free from heteroscedasticity symptoms 
Table 1.4 Hypothesis Testing

\begin{tabular}{lcccccc}
\hline Independent Variable & B & R2 & $\begin{array}{c}\text { Don't } \\
\text { count }\end{array}$ & Sig. & F count & Sig. \\
\hline Constant & 2,697 & & - & - & & \\
Sharia Marketing & 0,263 & $7.8 \%$ & 2,648 & 0,009 & 4,111 & 0.019 \\
Employee Intelligence & 0.104 & & 0,933 & 0,353 & & \\
\hline Source: data processing results (2020) & & & & &
\end{tabular}

Based on table 1.4 the results of multiple linear regression analysis, the formulation of multiple linear regression analysis models in this study is as follows: ${ }^{Y}=2,697+0,263 X_{1}+0,104 X_{2}+e$

Partial $\mathrm{t}$ test results $\backslash$ sharia marketing variablehas a $\mathrm{t}$ count of 2,648 greater than $\mathrm{t}$ table $(1,985)$ which shows that the sharia marketing variable affects public trust in Islamic banking. The significance value of the sharia marketing variable is 0.009 smaller than the specified significance value of 0.05 , so the sharia marketing variable has a positive and significant effect on public trust in Islamic banking so that the first hypothesis (H1) is accepted. This study is in line with research conducted by Halimah (2015) which states that Islamic marketing has a positive effect on public trust. Based on the responses of respondents through questionnaire statements, several things were obtained. The first statement is "Many Islamic banking advertisements are broadcast on Islamic TV"Respondents have a very good response because most people get information related to Islamic banking through advertisements broadcast on Islamic TV so that people gradually have a stigma of good trust in Islamic banking.

The next statement is "Islamic banking advertisements are often posted on social media", This statement received a very good response from the community. This is evident from the fact that people who are increasingly understanding social media have an easier time getting access to information regarding Islamic banking. In the third statement, namely "Islamic banking advertisements are broadcast on National TV and Radio"Most of the respondents have a good assessment. Statement next is "Islamic banking advertisements are plastered on Islamic magazines". This statement clearly received a positive response because the Muslim community has an interest in obtaining reliable information through Islamic magazines so that the inclusion of Islamic banking advertisements in Islamic magazines can attract public trust to switch from conventional banking to Islamic banking. The last statement is "Islamic banking advertisements are listed on the Friday bulletin at the mosque". The Muslim community has a good psychology for the information published through Islamic bulletin, especially the routine bulletin issued by mosque administrators. That way, public trust is increasingly fundamental to Islamic banking. From the analysis obtained through direct community involvement shows that the community has a good response to the sharia marketing strategy carried out by Islamic banking so that it can create a fundamental trust for Muslim communities who are not familiar with Islamic banking and can further increase trust for Muslim communities who have used Islamic banking.

Partial t test results employee intelligence variables hast count of 0.933 which is smaller than $t$ table (1.985) which shows employee intelligence variableshas no effect on public trust in Islamic banking. The significance value of the employee intelligence variable 0.353 is greater than the specified significance value, namely 0.05 , the employee intelligence variable has no and insignificant influence on public trust in Islamic banking so that the second hypothesis (H2) is rejected. This study is not in line with research conducted by Ludfi (2015) which revealed that employee performance has a positive and significant effect on public trust.

The results of this study are based on facts obtained from the results of the questionnaire responses in accordance with the statements given. The first statement is "Islamic banking employees have a polite and courteous attitude towards customers"Respondents have a good response because polite service has become the obligation of banking employees. The second statement is "Islamic banking employees have a good understanding of sharia principles". This statement also received a 
good response because the public assumed that it was only natural for a banking employee to understand well the principles of sharia. The third statement is "Islamic banking employees have an understanding of Islamic bank products". Some respondents are Muslim people who have just switched from conventional banking to Islamic banking so that people still depend on information explained by employees regarding Islamic bank products. In the fourth statement, namely "Islamic banking employees have a bachelor's degree and are Muslim" The public understands that banking has special qualifications for employees, thus graduate graduates and of course being Muslim are mandatory qualifications for banking employees. In the fifth statement, namely "Islamic banking employees have a religious appearance". For the public, this statement is an obligation for Islamic banking employees, because employees must be able to demonstrate sharia principles through the appearance of the uniform used.

Based on the responses from respondents, it shows that the public understands the good health of employees for Islamic banking. Starting from the appearance that reflects the principles of sharia to the capability of understanding the principles of sharia in banking. That way the public can easily understand how the principles of sharia and Islamic banking products are. Therefore, in the research, employee intelligence variables do not have an influence on public trust in Islamic banking.

The results of the simultaneous $F$ test show that the calculated $F$ value of 4.111 is smaller than the F table, namely 4.83 and the significant value of 0.019 is smaller than the determined significant alpha value of 0.05 so that simultaneously the regression model in this study results thatIslamic marketing variables and employee intelligence have no effect and but are simultaneously significant on public trust in Islamic banking. The study conducted simultaneous testing with the same results, namely that all variables had no but significant influence on public trust in Islamic banking. These results contradict research by Djati (2004) and Halimah (2017) which revealed that in their research, sharia marketing and employees are able to have a positive and significant influence on public trust. The coefficient of determination on the value of R Square (R2) in the first model is 0.078 or $7.8 \%$. It means thatcommunity marketing variables and employee intelligence dapat explain public trust in Islamic banking by $7.8 \%$. while the rest is indicated by the estimated error value, which is $92.2 \%$, explained by other variables not examined in this study such as the level of saving needs and others.

\section{CONCLUSION}

Based on the results of the research and discussion that has been done, conclusions can be drawn. Islamic marketing has a positive and significant effect on public trust in Islamic banking. Msociety shows that the community has a good response to the sharia marketing strategy carried out by sharia banking so that it can create fundamental trust for Muslim communities who are not familiar with sharia banking and can further increase trust for Muslim communities who have used sharia banking. Employee intelligence has no influence on public trust in Islamic banking. Mthe community has understood the good health of employees for Islamic banking. Starting from the appearance that reflects the principles of sharia to the capability of understanding the principles of sharia in banking. Islamic marketing and employee intelligence simultaneously do not have a positive but significant effect on public trust in Islamic banking. Based on the results of variable research, it was obtained that the $f$ value was 4.111 with the $\mathrm{f}$ table criteria of 4.83 or $\mathrm{f}$ count $<\mathrm{f}$ table and the significance value obtained was 0.019 which was smaller than 0.05 or sig. $<$ predetermined $\alpha$ value. 


\section{REFERENCE}

Alma, B. \& Priansa, D. J. (2014). Manajemen Bisnis Syariah: Menanamkan Nilai dan Praktik Syariah dalam Bisnis Kontemporer, Edisi Revisi. Bandung: Afabeta.

Anoraga, B. \& Prasettyo, A. (2015) Motivasi Kerja Islam Dan Etos Kerja Islam Karyawan Bank Jatim Syariah Cabang Surabaya. Bandung: Afabeta.

Khasanah, K. (2016). Pengaruh Karakteristik Marketing Syariah Terhadap Keputusan Menjadi Nasabah Bmt Ugt Sidogiri Cabang Pamekasan. Iqtishadia: Jurnal Ekonomi dan Perbankan Syariah, 1 (3), 123-144.

Kurniawan, A. (2014). Metode Riset Untuk Ekonomi \& Bisnis Teori, Konsep, dan Praktik Penelitian Bisnis (Dilengkapi Perhitungan Pengolahan Data dengan IBM SPSS 22.0). Bandung: Alfabeta.

Malau, H. (2017). Manajemen Pemasaran Teori dan Aplikasi Pemasaran Era Tradisional Sampai Era Global. Bandung : Alfabeta.

Ortega, D. \& Alhifni, A. (2017). Pengaruh Media Promosi Perbankan Syariah Terhadap Minat Menabung Masyarakat di Bank Syariah. EQUILIBRIUM: Jurnal Ekonomi Syariah 5 (1), 87-98.

Paramita, R. W. D., \& Rizal, N. (2018). Metode Penelitian Kuantitatif Buku Ajar Perkuliahan Metodologi Penelitian Bagi Mahasiswa Edisi 2. Bantul : Azyan Mitra Media.

Siregar, S. (2015). Metode Penelitian Kuantitatif dilengkapi dengan Perbandingan Perhitungan Manual \& SPSS. Jakarta : Prenamedia Group.

Sugiyono. (2009), Metode Penelitian Kuantitatif, Kualitatif dan R\&D. Bandung : Alfabeta.

Sugiyono. (2015a). Metode Penelitian \& Pengembangan Research and Development. Bandung: Alfabeta.

Sugiyono. (2015b). Metode Penelitian Kombinasi (Mxed Methods). Bandung: Alfabeta.

Sugiyono. (2015c). Metode Penelitian Kuantitatif, Kualitatif, dan Kombinasi (mixed methods). Bandung : Alfabeta.

Tjiptono, \& Chandra. (2017). Pemasaran Strategik Edisi 3 -Mengupas Pemasaran Strategik, Branding Strategy, Customer Satisfaction, Strategi Kompetitif hingga e-Marketing. Yogyakarta : CV.Andi Offset.

Tjiptono, F. (2016). Strategi Pemasaran. Yogyakarta : CV.Andi Offset.

Umar, H. (2011). Metode Penelitian Untuk Skripsi dan Tesis Bisnis Edisi Kedua. Jakarta: Rajagrafindo Persada.

Wijayani, D. R. (2017) Kepercayaan Masyarakat Menabung Pada Bank Umum Syariah. Muqtasid. Jurnal Ekonomi dan Perbankan Syariah 8 (1), 1-12.

Wiyono, G. (2011). Merancang Penelitian Bisnis dengan alat analisis SPPS 17.0 \& SmartPLS 2.0. Yogyakarta : UPP STIM YKPN. 